\title{
Analysis of Influences of Population Increase on Landuse Land Cover Change in Hong Local Government Area, Adamawa State, Nigeria
}

\author{
E. N. Gandapa*
}

Department of Geography, Nigerian Defence Academy, Kaduna, P.M.B. 2109, Kaduna, Kaduna State, Nigeria

DOI: $\underline{10.36348 / \mathrm{sjhss} .2020 . \mathrm{v} 05 \mathrm{i} 05.003}$

| Received: 16.10.2019 | Accepted: 23.10.2019 | Published: 30.05.2020

*Corresponding author: E. N. Gandapa

\section{Abstract}

Landuse land cover is subjected to continuous changes due to diverse and fluctuating human activities of the increasing population. The types of data required are landmass, population size, landuse land cover such as agricultural land, builtup area, bare land, water body and vegetation cover, and area covered by each. To determine the influences of population size on changes in agricultural land, built-up area, bare land, water body and vegetation cover the magnitude of each was divided by the population size to determine the per capita. Data on landmass was generated from topographic map; population size from National Population Commission; and landuse land cover and magnitude of each from landsat imageries. The imageries were analyzed using diverse GIS and Remote Sensing techniques. The results indicate magnitude of landuse land cover varied from $11.58 \%, 6.96 \%, 1.25 \%$ and $19.79 \%$ for agricultural land, bare land, built-up area and vegetation cover respectively. Likewise, population size increase by $10.82 \%$ while land per capita decreased by $7.74 \mathrm{~m}^{2}$ for the period under study. Result of simple correlation between population size and agricultural land, bare land, built-up area, water body and vegetation cover indicate $58 \%, 35 \%, 94 \%, 58 \%$ and $19 \%$ as percentage of determination. The result indicate with increase in population size by $10.82 \%$ leads to increase in density with 69 persons per $\mathrm{km}^{2}$ and land per capita decreased by $14.49 \mathrm{~m}^{2}$. The result implies with increase in population size lead to change landuse land cover.

Keywords: Spatio-temporal, Change detection, Landuse and land cover, Imageries, Comparison.

Copyright @ 2020: This is an open-access article distributed under the terms of the Creative Commons Attribution license which permits unrestricted use, distribution, and reproduction in any medium for non-commercial use (NonCommercial, or CC-BY-NC) provided the original author and source are credited.

\section{INTRODUCTION}

Environment is the natural surrounding which man depends on for sustenance and development [1,2]. Because of the diverse uses of land cover, man has changed the natural components of the landscape to satisfy his existence on the Earth's surface [3]. Environment and Natural Resources [5] maintained that with increase in harvesting of vegetation, soil fertility, minerals and expansion of roads and settlements have changed the land cover.

Studies especially those of Kilawe, Maliondo and Kajembe [5]; Mabogunje [6] observed that different landuse such as farmlands, built-up areas, road networks, and mining sites have expanded in Africa. Though, the changes are elements of development, but significantly accelerate changes in landuse land cover especially with increase in population $[7,8,10]$.

Zhang, Qi, Ye, Cai, Ma and Chen [11] in study on the relationship between landuse land cover change and population shift revealed there is difference in the spatio-temporal surface cover due to conversion of vegetation cover into dissimilar landuse such as farmlands and built-up area. Addae and Oppelt [12] used landsat imageries and population data of the same time period for landuse land cover change detection. The study revealed increasing population has resulted in the transformation of vegetation cover to residential areas, agricultural lands and bare lands.

Peter, Gadiga and Mshelia [13]; Suleiman, Saidu, Abdulrazaq, Hassan and Abubakar [14] researched on landuse land cover change detections in urban centres of Mubi, and Ilorin. The results indicate there were considerable changes in landuse land cover in the study areas. The results recommended people should integrate development and conservation measures.

Increase in population manifested by conversion of vegetation cover into agricultural land, built-up area and bare lands are important components 
of the transformation that have taken place in areas with a long history of human occupancies [15]. Therefore, understanding the rate and driving forces of landuse change is essential in environmental resource management $[16,17]$.

Result of study indicates that the tropical forests of Mexico are the most threatened worldwide, because of high pressures on human population density [18]. Therefore, it is necessary to conduct studies on spatio-temporal change detection at a micro scale in Sudan vegetation zone of Adamawa State to identify the linkage between population size and changes in landuse land cover.

Result of studies especially those of Addae and Oppelt [12]; Li et al. [15]; Sotelo-Caro et al., [18] on population size and landuse land cover change revealed that increase in population lead to changes in landuse land cover. However, these studies did not consider the influence of population size on landuse land cover change detection in Hong Local Government Area.

Result of recce to identify landuse land cover in Hong Local Government Area revealed that vegetation cover is ceding to farmlands, road networks and settlement sites. Furthermore, it is observed that vegetation reserves at Dzangula (Lat. $10^{\circ} 23^{\prime} \mathrm{N}$ and Long. $12^{0} 44^{\prime} \mathrm{E}$ ), Maki (Lat. $10^{0} 23^{\prime} \mathrm{N}$ and Long. $13^{0} 00^{\prime} \mathrm{E}$ ), Mararaba (Lat. $10^{0} 15^{\prime} \mathrm{N}$ and Long. $13^{0} 12^{\prime} \mathrm{E}$ ) and Kinging (Lat. $10^{0} 23^{\prime} \mathrm{N}$ and Long. $13^{0} 48^{\prime} \mathrm{E}$ ) (Garkida, Nigeria, Sheet 155) are significantly converted to farmlands on crops such as beans, maize, guinea corn and groundnuts.
It is from these perspectives that the research was conceived to assess the influences of population sizes on landuse land cover change. The objectives include: to determine landmass of the area; to identify agricultural land, bare land, built-up area, vegetation cover and water body and area covered by each; to identify the trends in population sizes; to deduce the influences of the detected trends in population sizes on landuse land cover changes; and to determine the level of relationship between population sizes and landuse land cover.

The study is restricted to Hong Local Government Area, Adamawa State, Nigeria. The period under study is from 1976 to 2009 with sample years of 1976, 1989, 1998 and 2009. The focus is to assess the influences of population sizes on landuse land cover changes.

\section{Geographic Background to Hong Local Government Area}

Hong Local Government Area lies between latitudes $09^{0} 57^{\prime} \mathrm{N}$ to $10^{0} 32^{\prime} \mathrm{N}$ and longitudes $12^{0} 38^{\prime} \mathrm{E}$ to $13^{0} 16^{\prime} \mathrm{E}$ as shown on Figure I. It has an approximate area of $2,486 \mathrm{~km}^{2}$ (Garkida, Nigeria, Sheet 155). The mean annual rainfall varies between 700 to $1000 \mathrm{~mm}$. The dry season is usually experienced from the months of November to April of the following year while the wet season is from May to October every year. The mean daily temperature is between $36^{0}$ to $41^{0} \mathrm{C}$ of the dry season to about $20^{\circ}$ to $25^{\circ} \mathrm{C}$ during the wet season [19]. The seasonal rainfall and high temperature causes changes in landuse land cover. For example, during the wet season there is significant water body while during the dry season it turns to bare land due to drying up of some surface water bodies.

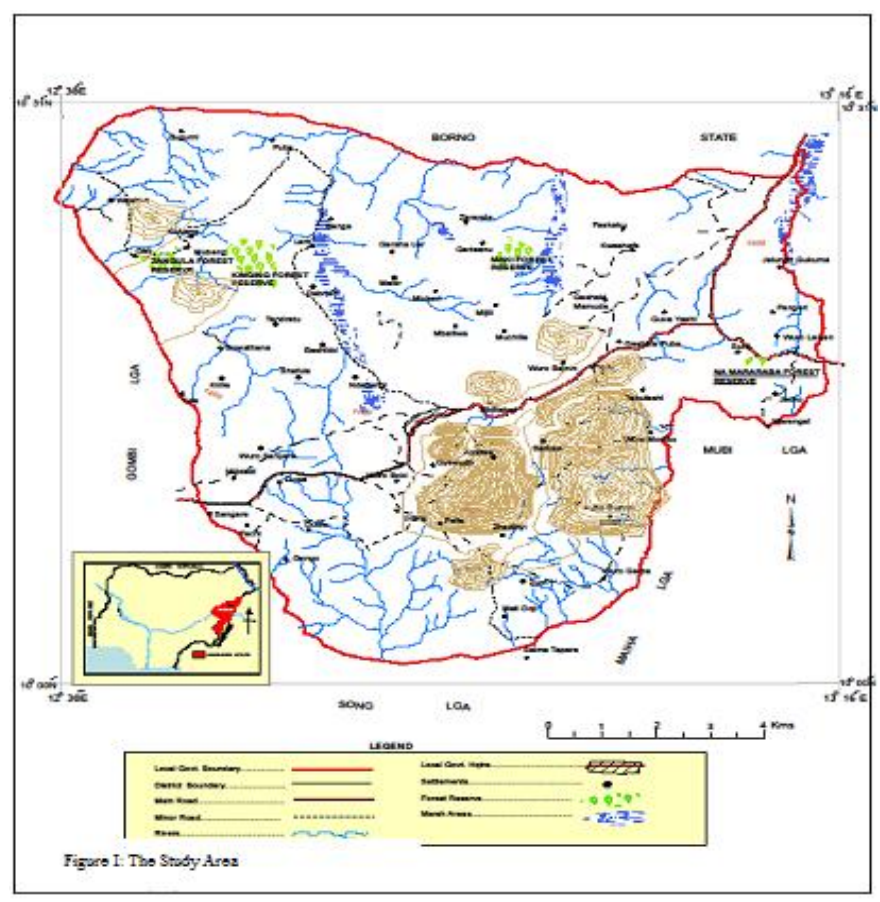

Fig-I: The Study Area 
The terrain consists of bare rock surfaces, water bodies, farmlands, vegetation covers, settlement sites and road networks. The relief and landforms are generally hilly with highlands ranging from about 426 to $1158 \mathrm{~m}$ above mean sea level [20]. These hills exhibit significant bare surfaces especially Ldam, Ngau and Kukurpu. In between the different highlands of various heights and sizes are pediments that are used for crop cultivation and settlements. The soils are well drained in most areas and favour arable farming on crops such as groundnuts, guinea corn, maize and beans. Ephemeral rivers such as Fa'a, Bubulum, Ngilang and Dogwaba causes variation in land cover. For example, water body in the wet season to bare surface in the dry season.

The vegetation lies within the Sudan zone [21]. The woody plants height ranges from less than $2 \mathrm{~m}$ to $14 \mathrm{~m}$ that are scattered with distribution ranging from 1 to 30 stands per $100 \mathrm{~m}^{2}$ with abundant grass cover [22]. The vegetation is exploited for fuelwood, shelter materials, charcoal and haft as well it is affected adversely by arable farming and over grazing.

The population increased from 112,845 in 1976 to 170,452 in 2009 occupying $2486 \mathrm{~km}^{2}$ [23]. The socio-economic activities of the populace that causes changes in landuse land cover in the area include: expansion of settlements, road networks, and arable farming on rotational bush fallow, mono cropping, continuous cropping, and crop rotation have transformed vegetation cover to agricultural land with adverse effects on vegetation cover. Significant mining started in the area in 1976 by Diestraccavalsecia (DTV); Armey Roadstone Company (ARC) in 1982; Julius Berger in 2003; and AG Vision in 2009 have converted significant portion of vegetation cover and farmlands to bare surfaces [22].

\section{MATERIALS AND METHODS}

The data required are agricultural land, bare land, built-up area, vegetation cover and water body, and magnitude of each. Others include landmass and human population sizes. The sets of data were used to determine the influences of population sizes on landuse land cover change. Data on landmass was generated from Garkida, Nigeria, Sheet 155 while population sizes were obtained from National Population Commission, Hong. Landsat imageries of 1976, 1987, 1998 and 2009 provide data on agricultural land, bare land, built-up area, water body and vegetation cover, and magnitude of each.

Using Topographical Sheet Series 37 and 38 (on scale 1: 250,000), the area span across two scenes (p. 185, r. 53; and p.186, r. 53). From the scenes, subsetting was done to demarcate the study area. Simultaneously, mosaicking was adopted to merge the two scenes. Signature files were developed using five colour bands to identify agricultural land, bare land, built-up area, vegetation cover and water body that were run on a supervised classification model that generate statistics for the signature files [24]. The emphasis is to determine the magnitude of the adopted landuse land cover. ArcGIS version 9.3 software was used to analyze the imageries using the following resolutions: 1976 MSS 50m (resample), 1987 TM 30m, 1998 TM 30m and 2009 ETM 15m. Accordingly, base map of Hong Local Government Area was imposed on the landsat imageries of 1976, 1987, 1998 and 2009 separately to produce landuse land cover maps.

To estimate the population of Hong Local Government Area from 112,845 in 1976 to 170,452 in 2009 , the 2006 census population figure $(169,183)$ was used [17]. Arithmetic method was accepted than geometric because it gives more conservative results [25]. The population growth rate of $2.6 \%$ was used to estimate the population [26].

To highlight the influences of population sizes on landuse land cover change, a model on population size and shift in landuse land cover was developed [6]. Thus, the model used different colours to identify five most observable categories of landuse land cover (agricultural land, vegetation cover, bare land, and built-up area and water body) of the area on landsat imageries, and magnitude of each was determined. The change detection was based on statistics generated for the various landuse land cover [27]. Detected magnitude in the landuse land cover categories were divided by the population sizes [28].

Quantitative evaluation of population trends and landuse land cover change is essential to identify the extent on environmental resources of a region [30]. To quantify the influences of population sizes on landuse land cover categories, the magnitude of the area was converted from $\mathrm{km}^{2}$ to $\mathrm{m}^{2}$ and divided by the population size of the same year to show land per capita in $\mathrm{m}^{2}$. Moreover, simple correlation and ' $\mathrm{t}$ ' test at $0.05 \%$ confidence limit were used to determine the magnitude of the relationship between population sizes and landuse land cover.

\section{RESULTS AND DISCUSSIONS}

From Figure II, vegetation cover is more concentrated from North West to the South and along rivers Fa'a, Bubulum and Dogwaba basins while bare land and built-up area correspond to the hilly regions, and around the more populated settlements like Hong and Pella among others.

Figure II presents pictorial data on agricultural land, bare land, built-up area, water body and vegetation covers. 


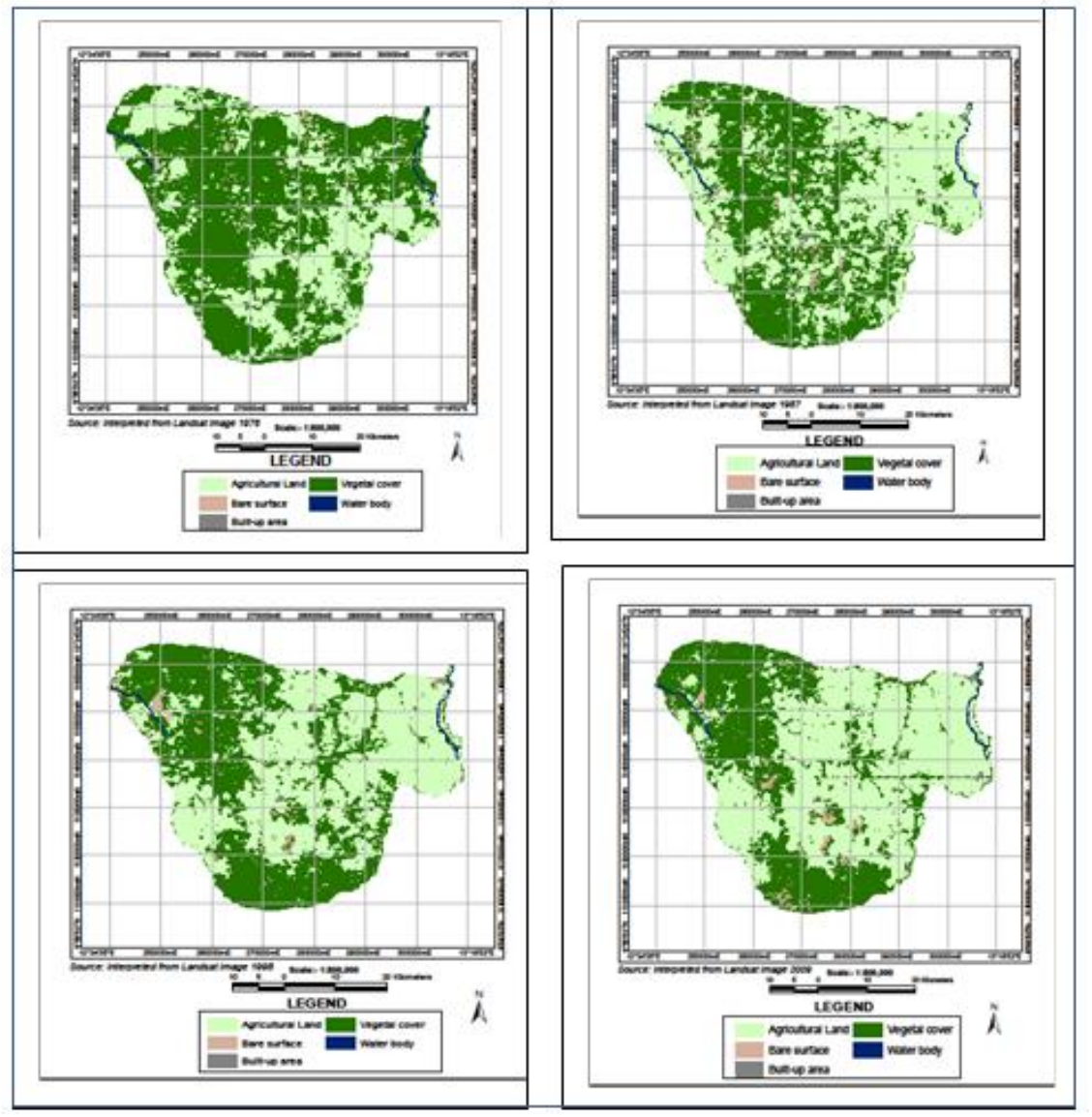

Fig-II: Landuse Land Cover Types of Hong Local Government Area Source: Landsat imageries of 1976, 1987, 1998 and 2009

Table 1 presents summary of the detected spatio-temporal trends in landuse land cover generated from Figure I.

Table-1: Detected Trends in Landuse Land Cover

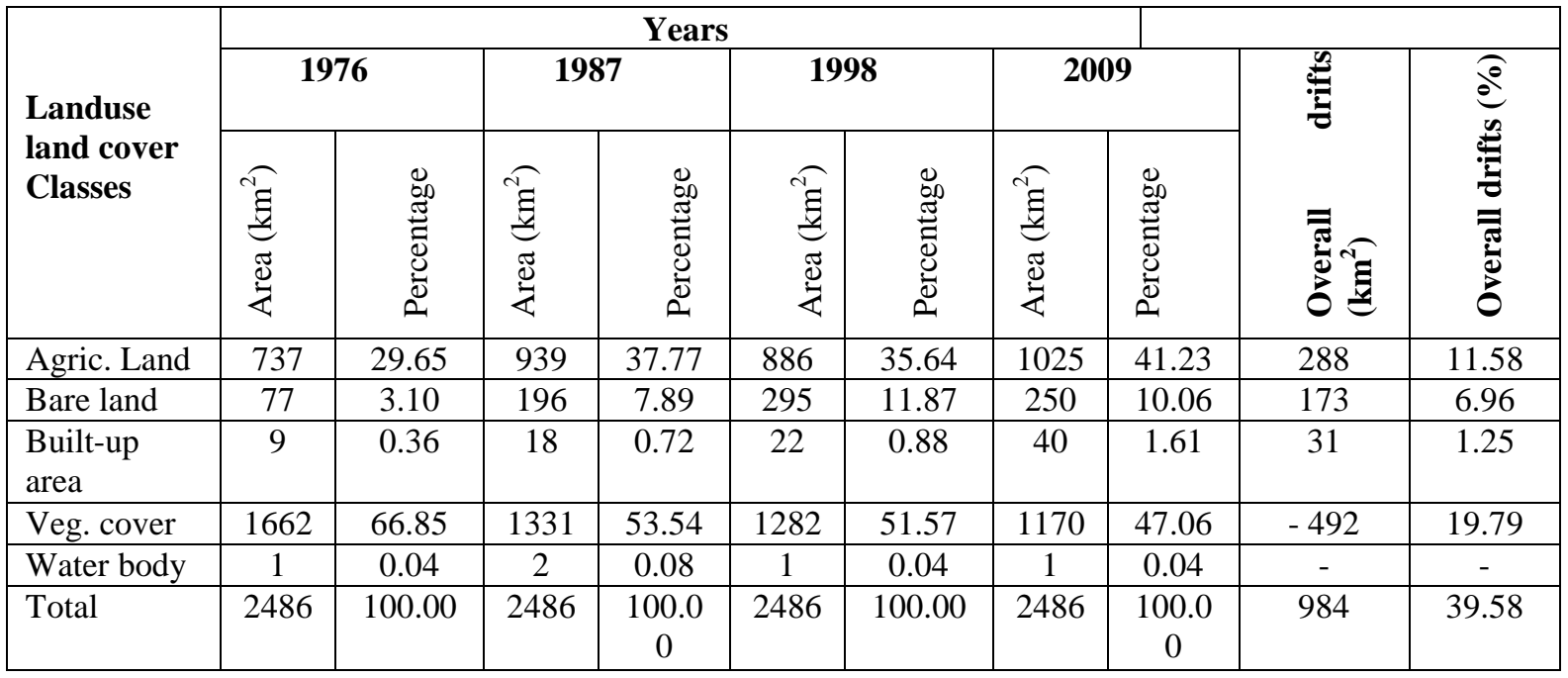

Source: Landsat Imageries: 1976, 1987, 1998 and 2009

From Table 1, agricultural land, bare land and built-up area increased by $11.58 \%, 6.96 \%$, and $1.25 \%$ while vegetation cover decreased by $19.79 \%$. However, water body indicates insignificant change.
Table 2 presents population trends and land per capita from 1976 to 2009. The population increased by $10.82 \%$ invariably the density increased from 45 to 69 persons per $\mathrm{km}^{2}$ while land per capita decreased from 22.22 to $14.49 \mathrm{~m}^{2}$. 
Table-2: Population Trends and Land per capita

\begin{tabular}{|c|c|c|c|c|}
\hline Year & Population & Percentage & Density $\left.\mathbf{( k m}^{\mathbf{2}}\right)$ & Land per capita $\left.\mathbf{( m}^{\mathbf{2}}\right)$ \\
\hline 1976 & 112,845 & 21.22 & 45 & 22.22 \\
\hline 1987 & 116,068 & 21.82 & 47 & 21.28 \\
\hline 1998 & 132,555 & 24.92 & 53 & 18.87 \\
\hline 2009 & 170,452 & 32.04 & 69 & 14.49 \\
\hline & & 100.00 & \multicolumn{2}{c|}{} \\
\hline
\end{tabular}

Source: NPC Hong and Field Study, 2010

Table 3 present detected trends in magnitude of landuse land cover, and the corresponding area per capita for the years under study. The per capita of agricultural land and vegetation covers decreased by 0.51 and $7.87 \mathrm{~m}^{2}$ while bare land and built-up area increased by 0.79 and $0.15 \mathrm{~m}^{2}$ respectively.

Table-3: Detected Trends in Magnitudes of Landuse Land Cover and Area per Capita

\begin{tabular}{|c|c|c|c|c|c|c|c|c|c|c|c|c|}
\hline \multirow[b]{2}{*}{$\begin{array}{l}\text { Landuse } \\
\text { land cover } \\
\text { classes }\end{array}$} & \multicolumn{3}{|c|}{1976} & \multicolumn{3}{|c|}{1987} & \multicolumn{3}{|c|}{1998} & \multicolumn{3}{|c|}{2009} \\
\hline & $\begin{array}{l}\text { Area } \\
\left(\mathbf{k m}^{2}\right)\end{array}$ & Pop & $\begin{array}{c}\text { Area } \\
\text { per } \\
\text { capita } \\
\left(\mathbf{m}^{2}\right) \\
\end{array}$ & $\begin{array}{l}\text { Area } \\
\left(\mathbf{k m}^{2}\right)\end{array}$ & Pop & $\begin{array}{c}\text { Area } \\
\text { per } \\
\text { capita } \\
\left(\mathbf{m}^{2}\right) \\
\end{array}$ & $\begin{array}{l}\text { Area } \\
\left(\mathbf{k m}^{2}\right)\end{array}$ & Pop & $\begin{array}{c}\text { Area } \\
\text { per } \\
\text { capita } \\
\left(\mathbf{m}^{2}\right) \\
\end{array}$ & $\begin{array}{l}\text { Area } \\
\left(\mathbf{k m}^{2}\right)\end{array}$ & Pop & $\begin{array}{c}\text { Area } \\
\text { per } \\
\text { capita } \\
\left(\mathbf{m}^{2}\right) \\
\end{array}$ \\
\hline $\begin{array}{l}\text { Agric. } \\
\text { Land }\end{array}$ & 737 & 112,845 & 6.53 & 939 & 116,068 & 8.09 & 886 & 132,555 & 6.68 & 1025 & 170,452 & 6.01 \\
\hline Bare land & 77 & & 0.68 & 196 & & 1.69 & 295 & & 2.23 & 250 & & 1.47 \\
\hline $\begin{array}{l}\text { Built-up } \\
\text { area }\end{array}$ & 9 & & 0.08 & 18 & & 0.16 & 22 & & 0.17 & 40 & & 0.23 \\
\hline Veg. cover & 1662 & & 14.73 & 1331 & & 11.47 & 1282 & & 9.67 & 1170 & & 6.86 \\
\hline Water body & 1 & & 0.01 & 2 & & 0.02 & 1 & & 0.01 & 1 & & 0.01 \\
\hline Total & 2486 & & & 2486 & & & 486 & & & 2486 & & \\
\hline
\end{tabular}

Source: Landsat Imageries and NPC Hong, 2010

\section{Influences of Population Sizes on Agricultural Land}

Result on the influences of population sizes on vegetation cover indicates that in the base year (1976) agricultural land was $737 \mathrm{~km}^{2}$ while the population was 112,845 . From the result, population increased by $10.82 \%$ (Table 2) at the same time agricultural land increased by $11.58 \%$ (Table 1). Because of increase in population the per capita of agricultural land decreased by $0.52 \mathrm{~m}^{2}$ from 1976 to 2009 (Table 3). This is because of increase in farmland to produce food for the increasing population. In between 1987 and 1998 agricultural land decreased by $2.13 \%$ because bare land and built-up area increased by $0.16 \%$ and $1.97 \%$ accordingly (Table 1). The reason for the increase in bare land and built-up area is due to increase in population by $3.10 \%$ (Table 2). Because of the increase in population the per capita of agricultural land decreased by $1.41 \mathrm{~m}^{2}$ (Table 3 ). The result implies with increase in population size leads to increase in agricultural land.

\section{Population Sizes and Bare Land}

From the result, bare land increased by $173 \mathrm{~km}^{2}$ (Table 1) while population increased by 57,607 from 1976 to 2009 (Table 2). The cause of increase in bare land by $6.96 \%$ is attributed to increase in road networks to serve the population that increased by $10.82 \%$. The increase in population by $10.82 \%$ has increased per capita of bare land by $1.55 \%$ (Table 3 ). In between 1998 and 2009 the decrease in bare land by $45 \mathrm{~km}^{2}$ $(1.81 \%)$ is due to increase in built-up area by $0.73 \%$ (Table 1). Likewise, population increased by $7.12 \%$
(Table 2) while per capita of bare land decreased by $0.76 \mathrm{~m}^{2}$ (Table 3).

\section{Population Sizes and Built-up Area}

From 1976 to 2009 the built-up area increased from $0.36 \%$ to $1.61 \%$ (Table 1 ) while population size increased from $21.22 \%$ to $32.04 \%$. The increase in population by $10.82 \%$ caused decrease in land per capita from 22.22 to $14.49 \mathrm{~m}^{2}$ (Table 2). From the results on table 3 , the per capita of built-up area increased by from 0.08 to $0.23 \mathrm{~m}^{2}$.

\section{Population Sizes and Vegetation Cover}

From Table 1, vegetation cover had the highest $(66.85 \%)$ la increased by 57,607 (Table 3). Because of the increase in population $(10.82 \%)$ the per capita of vegetation cover decreased by $7.87 \mathrm{~m}^{2}$ (Table 3 ).

\section{Population Sizes and Water Body}

The areas covered by water body remain at $1 \mathrm{~km}^{2}$ for the period under study (Table 1), and the population increased by 57,607 (Table 2). The average area of water body per the population indicates $0.01 \mathrm{~m}^{2}$. In between 1976 and 1987 water body increased by $0.04 \%$ (Table 1). The increase is due to decrease in vegetation cover by $13.31 \%$. This could be due erosion of vegetation along river banks that increased water body. 
Results of Correlation Tests between Population Sizes and Landuse Land Cover Change

To determine the level of relationship between population sizes and the categories of lanuse land cover the results on numerical values were subjected to simple correlation analysis. The results are presented on Table 4.

Table-4: Results of Simple Correlation and't' tests between Population Sizes and landuse land cover

\begin{tabular}{|r|c|c|c|c|c|c|}
\hline $\begin{array}{r}\text { Population size and landuse land } \\
\text { cover }\end{array}$ & $\mathbf{R}$ & $\mathbf{r}^{\mathbf{2}}$ & $\mathbf{r}^{\mathbf{2}} \mathbf{x} \mathbf{1 0 0}$ & $\begin{array}{c}\mathbf{1 0 0}- \\
\mathbf{r}^{\mathbf{2}}\end{array}$ & $\begin{array}{c}\text { Computed } \\
\mathbf{6} \mathbf{t}\end{array}$ & $\begin{array}{c}\text { critical } \\
\text { 't }\end{array}$ \\
\hline Population and agricultural land & 0.76 & 0.58 & $58 \%$ & $42 \%$ & 1.66 & 2.92 \\
\hline Population and bare land & 0.59 & 0.35 & $35 \%$ & $65 \%$ & 1.04 & 2.92 \\
\hline Population and built-up area & 0.97 & 0.94 & $94 \%$ & $6 \%$ & 5.60 & 2.92 \\
\hline Population and vegetation cover & -0.76 & 0.58 & $58 \%$ & $42 \%$ & -1.66 & 2.92 \\
\hline Population and water body & -0.43 & 0.19 & $19 \%$ & $81 \%$ & -0.68 & 2.92 \\
\hline
\end{tabular}

Source: Researcher's Compilation, 2019

From Table 4, the results of coefficient of correlation between population sizes and agricultural land, bare land and built-up area indicate positive, but high $\mathrm{r}=0.76,0.59$ and 0.97 respectively. This implies as population increases agricultural land, bare land and built-up area also increases and vice versa. However, the coefficient of correlation between population and vegetation cover $(r=-0.76)$ and population and water body $(r=-0.43)$ are negative. This implies with increase in population lead to decrease in vegetation cover and water body vice versa.

From the results, percentage of determination $\left(r^{2} \times 100\right)$ that agricultural land, bare land, built-up area, vegetation cover and water body are dependent on population size accounted for 58\%, 35\%, 94\%, 58\% and $19 \%$ respectively. The percentage of determination between population size and agricultural land, population size and vegetation cover are uniform (58\%), but varied from bare land (35\%), built-up area (94\%) and water body (19\%). These dissimilarities between population size and landuse land cover were due to increase in arable farming, settlements and roads construction. The result implies with increase in population size leads to increase in agricultural land, bare land and built-up area, but cause decrease in vegetation cover. Likewise, with increase in farmlands and built-up area manifested by increasing population leads to decrease in vegetation cover.

Other factors $\left(100-r^{2}\right)$ responsible for change in agricultural land, bare land, built-up area, vegetation cover and water body apart from population sizes reveal $42 \%, 65 \%, 6 \%, 42 \%$ and $81 \%$ individually. From the result, change in landuse land cover is significantly dependent on population size. However, changes in bare land and water body are insignificantly dependent on population size with $65 \%$ and $81 \%$ influences.

Comparing the computed ' $t$ ' values (1.66, $1.04,5.60,-1.66$ and -0.68$)$ to critical ' $t$ ' value all stand at 2.92 at $0.05 \%$ degree of freedom all the results falls within the accepted limit except population size and built-up area with ' $t$ ' value of 5.60 that falls outside the acceptance region. From the values of coefficient of correlation, percentage of determination, and the ' $t$ ' tests the null hypothesis that there is no statistical relationship between population sizes and changes in agricultural land, bare land, built-up area, vegetation cover and water body is not accepted. Hence, the alternative hypothesis that there is statistical relationship between population sizes and changes in landuse land cover is accepted.

To this end, there are similarities in the results of the study to those of Addae and Oppelt [12]; Zhang et al., [11]; Kilawe et al. [5]; and Ballinger [3] that with increase in population sizes leads to changes in landuse land cover (agricultural land, bare land, built-up area, vegetation cover and water body).

\section{CONCLUSION}

Based on the findings of this study, there is significant relationship between population sizes and changes in landuse land cover. Increase in population by $10.82 \%$ is responsible for increase in agricultural land, bare land and built-up area by $11.58 \%, 6.96 \%$ and $1.25 \%$ while vegetation cover decreased by $19.79 \%$. Land per capita for agricultural land and vegetation cover decreased by $0.52 \mathrm{~m}^{2}$ and $7.87 \mathrm{~m}^{2}$ while bare land and built-up area increased by $0.79 \mathrm{~m}^{2}$ and $0.15 \mathrm{~m}^{2}$ respectively. From the result, the magnitude of relationship between population sizes and agricultural land, bare land, built-up area, vegetation cover and water body indicate $58 \%, 35 \%, 94 \%, 58 \%$ and $19 \%$ respectively.

\section{RECOMMENDATIONS}

Based on the results of findings, the study recommends policy makers should provide guidelines on landuse land cover management to protect environmental resources like vegetation cover and water body for sustainable development. More importantly, landuse policy should be strictly enforced to conserve the decreasing vegetation cover.

\section{ACKNOWLEDGEMENTS}

I am grateful to Brig. Gen. Philip M. Atere Ph.D. (rtd) for valuable inputs on the manuscript. 
Others include Mr. John Samuel Gandapa, Mr. Jackson Ismaila Matapa, Mr. Falnyi Ismaila Garki, Mrs. Dorcas Iliya Bello and Josiah E. Nyako for their contributions during data collection.

\section{REFERENCE}

1. Helfrich, C. (2018). Activism AfterHours (Doctoral dissertation, The University of the Arts).

2. Kinhal, V. (2019). Why Is Our Environment Important? Available: https://greenliving.lovetoknow.com/Why_is Our_Environment_Important Accessed 20 January, 2019

3. Ballinger, C. (2011). Environmental Determinism. Available: http://en.wikipedia.org Accessed 30 March, 2018

4. Environment and Natural Resources. (2015). Landscape Changes. Available: https://www.enr.gov.nt.ca/en/state- environment/8landscape-changes Accessed 20 January, 2019

5. Kilawe, C.J., Maliondo, S.M.S., \& Kajembe, G.C. (2012). Shifting Cultivation Nightmare: Effects on Forest Cover Change and Soil Nutrients Dynamics in Tanzania. Available: http://bsuec.org Accessed 30 March, 2018

6. Mabogunje, A.L. (2010). The Environmental Challenges in Sub Saharan Africa. Available: https://www.tandfonline.

com/doi/abs/10.1080/00139157.1995.9929233?jour nalCode=venv20 Accessed 13 November, 2018

7. Choudhary, V. (2019). Population Growth and Its Impacts on Nature and Natural Resources. Available: http://natureconservation.in/populationgrowth-and-its-impacts-on-nature-and-naturalresources/ Accessed 20 January, 2019

8. Pellikka, P.K.E., \& Siljander, M. (2018). Land Cover Change. In: Anthropocene Volume 21(4151) Available: https://www.sciencedirect.com/topics/earth-andplanetary- sciences/land-cover-change Accessed 20 January, 2019

9. Allen, C.D., Macalady, A.K., \& Chenchouni, H. (2010). A Global Overview of Drought and Heatinduced Tree

10. Mortality Reveals Emerging Climate Change Risks for Forests. Forest Ecology and Management. Elsevier B.V. Publishing. Net Library. Available: www.elsevier.com/locate/foreco Accessed 30 July, 2016. Pp. 661-669

11. Zhang, H., Qi, Z., Ye, X., Cai, Y. Ma, W., \& Chen, M. (2013). Analysis of land use/land covers change, population shift, and their effects on spatiotemporal patterns of urban heat islands in metropolitan Shanghai, China. Applied Geography Vol.44, 121-133. Available: https://www.sciencedirect.com/science/article/abs/ pii/ S0143622813001823 Accessed 7 July, 2019
12. Addae, B., \& Oppelt, N. (2019). Land-Use/LandCover Change Analysis and Urban Growth Modeling in the Greater Accra Metropolitan Area (GAMA), Ghana. Available: http://int.search.myway.com/search/GGmain. jhtml?p2=\%5EY6\%5Expv185\%5ETTAB02\%5Eng $\& \mathrm{ptb}=25 \mathrm{~B} 2 \mathrm{~A} 743-\mathrm{B} 984-4 \mathrm{~F} 9 \mathrm{C}-$

84B1388F744BDAC8\&n=

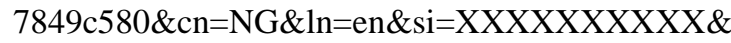
tpr=hpsb\&trs=wtt\&brwsid=1835f68f-4262-47e2af1a-

$55706 \mathrm{fb} 76009 \&$ searchfor $=$ landuse + land + cover $+\mathrm{ch}$ ange+and+population \&st=hp Accessed $2^{\text {nd }}$ July, 2019

13. Peter, Y., Gadiga, B.L. \& Mshelia, A.D. (2015). "Landuse/land Covers Change Detection of Mubi Metropolis, Adamawa State, Nigeria". In: Sky Journal of Social and Environmental Management 4(6) 070-078. Available: http://www.skyjournals.org/SJSSEM Accessed 7 July, 2018

14. Suleiman, Y. M., Saidu, S., Abdulrazaq, S.A., Hassan, A.B., \& Abubakar, A.N. (2014). The Dynamics of Landuse Land Cover Change: Using Geospatial Techniques to Promote Sustainable Urban Development in Ilorin Metropolis, Nigeria. In: Asian Review of Environmental and Earth Sciences 1(1). Available: http://www. asianonlinejournals.com.index Accessed 7 July, 2018

15. Li, F., Zhang, S., Bu, K., Yang, J., Wang, Q., \& Chang, L. (2015). The relationships between Land Use Change and Demographic Dynamics in Western Jilin Province. Journal of Geographical Sciences, 25(5): 617-636 Available: http://www.geogsci.com/article/2015/1009637X/36519 Accessed $2^{\text {nd }}$ July, 2019

16. Tilman, D., \& Lehman, C. (2017). Human-caused Environmental Changes: Impact on Plant Diversity and Evolution. Available: http://www.pnas.org/content/98/10/5433.ful Accessed 2 September, 2018

17. Nath, D.C., \& Mwchahati, D.D. (2012). "Population Increase and Deforestation: A Study in Kokrajhar District ofAssam, India". In: International Journal of Scientific and Research Publications. 2 (10) ISSN 2250-3153. Available: https://search.yahoo.com/yhs/searchp= the+relationship+between+population+and+trees+ density Accessed 2 September, 2018

18. Sotelo-Caro, O., Chichia-González, J., Sorani, V. and Flores-Palacios, A. (2015). Changes in the Deforestation Dynamics of a River Sub-Basin of Mexico: Non-Recovery of Primary Habitats Following Cessation of Deforestation. Available: https://scielo.conicyt.cl/scielo.php?script=sci_arttex t\&pid=S0718- 34022015000200011 Accessed 7 July, 2019

19. Online Nigeria. (2017). Climate of Nigeria. Accessed 26 January 2016. Available: 
http://www.onlinenigeria.com/

links/adv.asp?blurb=70 Accessed 7 July, 2018

20. Garkida, Nigeria, Sheet 155

21. Nigerian Scholars. (2019). Vegetation Zones in Nigeria. Available:

https://nigerianscholars.com/tutorials/ecologyoverview/nigerian-biomes/ Accessed 20 January, 2019

22. Gandapa, E.N. (2014). Analysis of Effects of Human Activities on Vegetation of Hong Local Government Area,Adamawa State, Nigeria: Ph.D. Thesis. Department of Geography, Nigerian Defence Academy, Kaduna, Nigeria, 18-20, 31-41, 85

23. National Population Commission. (2010). Federal Republic of Nigeria, 2006 population and housing census priority table volume III; population distribution by sex, state, LGA and senatorial district. Abuja, Nigeria: National Population Commission.

24. ERDAS Imagine. (1997). Field Guide Inc. Atlanta, Georgia, USA. 33, 34, 213, 214

25. Zohry, A. (2012). Methods of Measuring Population Change. Available: http://r.search.yahoo.Com/ylt=A0LEVjw T3a9ZxpUAgs 0PxQt.;ylu Accessed 6 September, 2018

26. World Data Atlas. (2016). Nigeria-Population-Rate of natural increase. Available: https://knoema.com/atlas/Nigeria/ topics/Demographics/Population/Rate-of-naturalincrease Accessed 16 September, 2018

27. Omer, G. E. K. (2009). Impact Of Land Use Changes on Vegetation Cover and Sustainable
Livelihoods along the Banks of Niles at Khartoum State, Sudan. Available: http://int.search.myway.com/search/GGmain. jhtml?p2=\%5EY6\%5Expv185\%5ETTAB02\%5Eng $\& p t b=25 B 2 A 743-B 984-4 F 9 C-84 B 1-$

388F744BDAC8

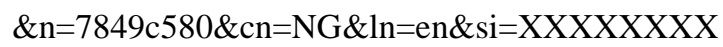
$\mathrm{XX} \& \mathrm{tpr}=\mathrm{hpsb} \& \mathrm{trs}=\mathrm{wtt} \&$ brwsid $=1835 \mathrm{f} 68 \mathrm{f}-4262-$ 47e2-af1a$55706 \mathrm{fb} 76009 \&$ searchfor=Implications+of+Landu se+Changes+on+Vegetation + Cover $+\&$ st $=$ hp Accessed 7 July, 2029

28. Fonge, B. A., Tabot, P. T., Bakia, M. A., \& Awah, C.C. (2019). Patterns of Land-Use Change and Current Vegetation Status in Peri-Urban Forest Reserves: The Case of the Barombi Mbo Forest Reserve, Cameroon. Journal of Geology, Ecology, and Landscapes 3(2). Available: https://www.tandfonline.com/doi/full/ 10.1080/24749508.2018.1508981 Accessed 7 July, 2019

29. Liu, F., Qin, T., Girma, A., Wang, H., Weng, B., Yu, Z., Wang, Z. (2019). Dynamics of Land-Use and Vegetation

30. Change Using NDVI and Transfer Matrix: A Case Study of the Huaihe River Basin. Pol. J. Environ. Stud. 28(1), 213-223 Available: http://int.search.myway.com/search/GGmain. jhtml?n=7849c580\&p2=\%5EY6\%5Expv185\%5ET TAB02\%5Eng\&ptb=25B2A743-B984-4F9C84B1388F744BDAC8\&qs $=\& s i=X X X X X X X X X X$ $\& s s=$ sub\&st=hp\&trs=wtt\&tpr=sbt\&enc $=2 \&$ searchf or Accessed 7 July, 2019. 